\title{
Decolonial Studies, Non-Extractive Methods, and Participatory Action Research in Accounting
}

\author{
Estudos Decoloniais, Métodos Não Extrativistas e Pesquisa-Ação \\ Participativa em Contabilidade
}

\author{
Cleia Maria da Silva*1,2 $\odot$ \\ Fernanda Filgueiras Saverbronn ${ }^{2 \oplus}$ \\ Michel Thiollent ${ }^{30}$
}

\section{ABSTRACT}

Objective: this paper discusses how accounting supports financial capitalism in the Global South through neocolonialist languages and practices, aiming to put forth a decolonial agenda based on non-extractive methodologies to recover alternative knowledge and (re)build new ones. Method: we revisited critical accounting literature, connecting it to decolonial epistemology. We described the assumptions behind different non-extractive methods and contrasted participatory action research (PAR) with different approaches to knowledge production and consumption. We also outlined some PAR operational strategies, discussed action research in management and accounting studies, and examined the potential for a participatory accounting agenda. Results: non-extractive methods can respect and value different worldviews in each social phenomenon. This points to non-traditional and emancipatory research alternatives to produce a new sentipensante in accounting to decolonize knowledge, bodies, and minds. Conclusions: this paper presents PAR as allowing (re)existence of different worldviews by recognizing its ability to recover and rebuild knowledge 'with' participants. PAR supports programmatic engagement with subalternized voices to coproduce pluriversality in accounting — instead of reproducing universalisms — and bolsters academics and practitioners to transcend Western modernity.

Keywords: accounting; decoloniality; non-extractive methods; participatory action research.

\footnotetext{
* Corresponding Author.

1. Universidade Federal Rural do Rio de Janeiro, Departamento de Ciências Contábeis e Finanças, Seropédica, RJ, Brazil.

2. Universidade Federal do Rio de Janeiro, Programa de Pós-Graduação em Ciências Contábeis, Rio de Universidade Federal
Janeiro, RJ, Brazil.

3. Universidade Federal do Rio de Janeiro, Núcleo Interdisciplinar para o Desenvolvimento Social, Rio de Janeiro, RJ, Brazil

Cite as: Silva, C. M., Sauerbronn, F. F., \& Thiollent, M. (2022). Decolonial studies, non-extractive methods, and participatory action research in Accounting. Revista de Administração Contemporânea, 26(4), e210014. https://doi.org/10.1590/1982-7849rac2022210014.en

Published as Early Access: November 23, 2021

Assigned to this issue: January 06, 2022.
}

\# of invited reviewers until the decision:

\# of invited reviewers until the decision:

\section{RESUMO}

Objetivo: o artigo discute como a contabilidade apoia o capitalismo financeiro no Sul Global por meio de linguagens e práticas neocolonialistas, com o objetivo de propor uma agenda decolonial baseada em metodologias não extrativistas para recuperar conhecimentos alternativos e (re)construir novos. Método: revisitamos a literatura contábil crítica, conectando-a à epistemologia decolonial. Portanto, descrevemos os pressupostos por trás de diferentes métodos não extrativos, e contrastamos a pesquisa-açáo participativa (PAR) com diferentes abordagens de produção e consumo de conhecimento. Também foram delineadas algumas estratégias operacionais da PAR, discutindo pesquisa-açáo em estudos de gestáo e contabilidade e o potencial para uma agenda participativa em contabilidade. Resultados: os resultados evidenciam métodos não extrativistas para respeitar e valorizar diferentes visóes de mundo em um determinado fenômeno social. Assim, são apontadas alternativas de pesquisa não tradicionais e emancipatórias para produzir um novo "sentipensante" na contabilidade para descolonizar saberes, corpos e mentes. Conclusóes: este artigo apresenta a PAR como permitindo a (re)existência de diferentes visóes de mundo ao reconhecer sua capacidade de recuperar e reconstruir o conhecimento "com" os participantes. Assim, o método apoia o engajamento programático com vozes subalternizadas para coproduzir a pluriversalidade na contabilidade em vez de reproduzir universalismos e para apoiar acadêmicos e profissionais para transcender a modernidade ocidental.

Palavras-chave: contabilidade; decolonialidade; método não extrativista; pesquisa-açáo participativa.

JEL Code: M190, M490

Editors-in-chief: Wesley Mendes-da-Silva (Fundação Getulio Vargas, EAESP, Brazil) [0] Marcelo de Souza Bispo (Universidade Federal da Paraiba, PPGA, Brazil) 영 Guest Editors: Evelyn Lanka (Cranfield School of Management, United Kingdom) (C) Sanjay Lanka (Fundação Getulio Vargas, EAESP, Brazil) Ali Rostron (University of Liverpool, United Kingdom) Pallavi Singh (Sheffield Hallam University, United Kingdom) (] Reviewers: Maria Ceci Araujo Misoczky (Universidade Federal do Rio Grande do SUl, DCA, Brazil)
One of the reviewers chose not to disclose his/her identity.
Peer Review Report: The Peer Review Report is available at this external URL. Reviewers: Maria Ceci Araujo Misoczky (Universidade Federal do Rio Grande do Sul, DCA, Brazil)
One of the reviewers chose not to disclose his/her identity.
Peer Review Report: The Peer Review Report is available at this external URL. Received: January 15, 2021 Last version received: June 23, 2021 Accepted: September 29, 2021 


\section{INTRODUCTION}

As an applied social science, accounting controls and captures the economic order's measurement, based on global financial capitalist models, to transmit information to its internal and external users (Chiapello, 2017). Based on financialized and non-neutral rationality (Cooper, 2015; Godowski, Nègre, \& Verdier, 2020; Oakes \& Oakes, 2016), accounting is an integral and fundamental part of capitalism, with colonialist features that support a specific global political economy (Godowski et al., 2020; Hussain, Liu, \& Miller, 2020).

Accounting has a colonialist trajectory reflected in thematic and methodological choices of mainstream research, regarded as neutral due to its predominantly neoclassical economics and quantitative methods (Gendron \& Baker, 2005; Malsch, Gendron, \& Grazzini, 2011). In Brazil, qualitative research in accounting is mostly functionalist and restricted to traditional methods, such as case studies and documentary research (Pereira, Constantino, Sauerbronn, \& Macedo, 2019; Santos, 2019). Even in management accounting - considered the most open to other approaches - , 56\% of dissertation research is still functionalist; $34 \%$ is interpretive, and only $1.4 \%$ is considered "humanist" (Azevedo, Barbosa, Consoni, \& Espejo, 2020, p. 2940). We challenge the dominant scenario in Brazil (Lourenço \& Sauerbronn, 2016) through a decolonial perspective and its potential to dislocate accounting research-practice beyond coloniality, Eurocentrism, and racialized hierarchies (Kim, 2004; Sauerbronn, Ayres, \& Lourenço, 2017).

Our perspective seeks to (re)naturalize social reality by considering that individuals, groups, space, and time are distinct and complex (Mignolo, 2007a; Mignolo \& Walsh, 2018; Quijano \& Ennis, 2000). Hence, this essay does not propose a naive defense of qualitative methods, as it recognizes criticisms of its system of rigid understanding due to the schematic logic of traditional science (Meneghetti, 2011). In this sense, we highlight that qualitative research has gone through different phases or "moments" (Denzin \& Lincoln, 2005, p. 1). These moments mark their trajectory and development involving the rigor-relevance debate and criticism of functionalist ethnographies, seen as a colonialist project for observing "the other" under a Eurocentric, "racist project" (Denzin \& Lincoln, 2005, p. 2). In the last few decades, qualitative research arising from multicultural, black, and gender activism has challenged colonial domination in methodologies (Denzin \& Lincoln, 2005; Denzin, 2018).

We propose overcoming the colonial, racialized, gendered, and patriarchal legacy of Eurocentric epistemology and qualitative research through decolonial, non-extractive methods/perspectives, as suggested by Santos (2019) and Barbosa (2018). This approach presupposes subjects that coconstitute social reality (Gómez, 2019). They are not merely objects of research to be extracted, captured, measured, and quantified. Researchers must unveil possibilities of non-extractive methodologies from the decolonial ontoepistemological perspective (Santos, 2019; Walsh, 2007). According to Santos (2007), non-extractivism aims to produce knowledge "on the other side of the abyssal line," which is a space of "non-existence, invisibility, and nondialectic absence" (Santos, 2007, p. 71). This is, therefore, a propitious and perhaps unknown universe to researchers in accounting (Sauerbronn, Ayres, Silva, \& Lourenço, 2021). It is possible to change the form of sentipensar (feelingthinking) the world (Fals-Borda, 2009), to (re)exist and (re) built grand 'narratives,' also in accounting.

We argue that the non-extractive methodologies/ perspectives enable the construction of knowledge 'with' the participants/individuals of a particular social context, rather than 'about' specific individuals, in a distant manner, and brought forth by the researcher (Meneghetti, 2011; MotaNeto, 2018; Santos, 2019; Thiollent, 1986). Therefore, we revisit participatory action research (PAR) to contribute to a decolonial programmatic practice in accounting from the margins. This implies recognizing (a) PAR's cyclical proposition and processes of change (Tripp, 2005), (b) the coexistence of a pluralistic reality based on different worldviews of individuals and their ontologies (FalsBorda, 1979; 2009; Freire, 1987; 1992; Fasanello, Nunes, $\&$ Porto, 2018), and (c) that knowledge materializes and gains meaning in embodiment (Glassman \& Erdem, 2014; Santos, 2019).

The next sections discuss: (a) the colonialist trajectory in accounting, (b) the potential contribution from decolonial epistemology, (c) the conceptualization of the non-extractive methodology aligned with southern epistemologies, and (d) assumptions and methods in PAR, including previous studies in management and accounting in Brazil. Finally, we explore some pitfalls and potential for investigating emerging social problems in accounting, based on Paulo Freire's (1921-1997) emancipatory pedagogy and Orlando Fals-Borda's (1925-2008) investigación-acción participativa and sentipensante.

\section{COLONIALITY IN ACCOUNTING}

The colonialist legacy of accounting goes back to its use as a mechanism to record, disclose, and distribute/ concentrate wealth in sixteenth-century European colonial expansion, in Latin America and subsequently in North America, Africa, and Asia. 
Historically, in Latin America and in Brazil, accounting and taxation provided support to 'slave-related transactions' in the $18^{\text {th }}$ and $19^{\text {th }}$ centuries through "recording taxation, inventory lists, rental agreements, insurance policies, and receipts" (Rodrigues, Craig, Schmidt, \& Santos, 2015, p. 43). Silva, Vasconcelos, and Lira (2021) revealed how accounting inscriptions regarding the 'emancipation fund' functioned as 'governmentality apparatuses' to transition from slavery to wage-labor relations with advantages to former slave owners.

In Rio de Janeiro, the School of Commerce was rethought as part of Portugal's identity to facilitate the creation of a new center, such as through the use of bookkeeping for doubles and other technologies, to consolidate a hegemonic image of the Portuguese Empire (Araújo, Rodrigues, \& Craig, 2017). Accounting also played a significant role in the Eurocentric modernizing process, during the transition from agrarian to industrial economics in the 19th century. By the end of the $20^{\text {th }}$ century, the early influence of the Italian School on accounting had also shifted to an obvious one from North American thinking (Rodrigues, Schmidt, Santos, \& Fonseca, 2011).

In Trinidad and Tobago, a former British colony, Annisette's (2000) work illustrated the influence of coloniality on accounting through accounting professionals' certification. The local accounting elite strives to undermine any nationalist accounting project, aiming to perpetuate imperialism. Also in the Caribbean, Bakre (2014) discussed how imperialism's structure reflects colonialism and the external pressure of globalization, which hamper the integration of regional accounting.

According to Davie (2000), the expansion of imperialism in the South Pacific reveals how accounting has become involved in producing formal calculating knowledge, imposed by elitist processes of domination and control by means of accounting calculations and explanations. Neu, Everett, and Rahaman (2009) studied how international organizations used accounting to modernize government practices in Mexico, making these organizations become part of that geography.

As an example, Alawattage and Wickramasinghe (2009) studied the Ceylon plantations of present-day Sri Lanka. They addressed British colonial influence in the local development of hybrid structures of control and accountability, which formed a combined outcome of both feudal and imperial political and administrative mechanisms. Hence, accounting structured a system of debt and interest involving workers and employers. This was a perverse system of bonded labor, officially abolished only in 1976 by the Bonded Labor System (Abolition) Act.
In Africa, for instance, the work of Lassou, Hopper, Tsamenyi, and Murinde (2019) revealed varieties of neocolonialism through accounting in Ghana and Benin. They contended that, despite not being monolithic agents, "former colonial powers still influence accounting through monetary systems, international financial institutions, political advisors, Northern accounting associations and neopatrimonialism" (Lassou, Hopper, Tsamenyi, \& Murinde, 2019, p. 1). While the French approach is perceived as 'coercive-neo-colonialism' due to French advisors exerting direct control, the British enforce a 'soft-neo-colonialism' based on accounting and infrastructure, also influenced by the USA.

As in Oakes and Oakes (2016), studies have also indicated that colonialism corrupts, destroys, and hinders the capacity for criticism and resistance to the contents and forms of accounting, confining it to its role as an instrument of the dominant power at the service of global financial capitalism (Godowski et al., 2020). However, accounting "as a communicative social practice" is simultaneously emancipatory and repressive (Gallhofer \& Haslam, 2019, p. 7). A plural social context matters, even though it is not free from calculating systems or prejudice and does not solve neutrality problems (Oakes \& Oakes, 2016).

The critical accounting literature has illustrated possibilities beyond conventional accounting theories. Accounting has previously pointed to the need for accounting and accountability activism (Shenkin \& Coulson, 2007) and the development of collective intellectual stances (Cooper \& Coulson, 2014). Hence, empirical studies have crafted new modes of thinking-doing, becoming more dialogical, emancipatory, and hybrid (Godowski et al., 2020; Hussain et al., 2020). Studies must recognize that accounting has the power to neglect, suppress, or hegemonize subaltern knowledge (Sauerbronn et al., 2017), and hegemonic forces can capture emancipatory initiatives (Sikka, 2008).

An emancipatory accounting perspective has been transformed in the past few decades. Reflecting the influence of post-structuralist, postmodern, and post-Marxist thought, it has moved away from rigid dichotomies and revolutionary tenets in critical theorizing, heading toward radical progressive projects (Gallhofer \& Haslam, 2019). Critical and transformative accounting researchers have been expanding their investigations into the possibilities of individuals' socio-political emancipation toward a new world, a real-world, based on collective social participation in favor of marginalized and oppressed groups (Célérier \& Botey, 2015).

By transposing onto-epistemological traditions to the realm of methods, accounting research can transcend conventional practices, challenging the centrality of EuroAmerican ideas and methods. Such criticism must consider 
how the "eternally optimistic but perpetually failing nature" (Neu \& Heincke, 2004, p. 179) of accounting techniques of governance (and of research) have been used in colonial contexts to control and avoid popular resistance (Neu \& Heincke, 2004). Therefore, the decolonial approach we propose aligns with the propositions of Sauerbronn, Ayres, and Lourenço (2017) and Sauerbronn, Ayres, Silva, and Lourenço (2021) as a possibility for qualitative research that challenges the colonialist trajectory of accounting in Brazil and other countries in the margins of capitalism.

We strive to bring accounting closer to naturalistic approaches that incorporate plural voices engaged in reexisting and resisting Western colonialism (Mota-Neto, 2018). The next section discusses some methodological claims of the decolonial epistemology movement (DEM) to distinguish it in terms of practice to decolonize knowledge and minds, including the researcher's (Sauerbronn et al., 2021). The coloniality-modernity compound (Quijano \& Ennis, 2000) has affected social and economic relations globally for at least 500 years. The next section also addresses its three essential elements: (a) coloniality of power, knowledge, and mind; (b) capitalism; and (c) Eurocentrism.

\section{CONTRIBUTIONS FROM DECOLONIAL THOUGHT}

Anibal Quijano and Ennis (2000) described the coloniality of power, being, and knowledge as an imposition of the idea of domination by colonizing nations. Such imposition was decisive for the constitution of the nationstate as we know it, based on a global power model of capitalism (colonial/modern) under the influence of Eurocentrism. Beginning in the 16th century, European empires (Portugal, Spain, England, and France) forged this new mode of power sustained by two fundamental axes: (a) the idea of 'race,' causing some individuals (Africans and original, colonized peoples) to be inferior to others (whites, colonizers); and (b) the idea of 'work,' forged by a structure of control over resources and products arising from slavery and servitude based on capital and the world market (Quijano \& Ennis, 2000).

According to Quijano and Ennis (2000), as a financial and accounting element, capitalism is related to the emergence of commercial relations in the $15^{\text {th }}$ or $16^{\text {th }}$ centuries around the south of the Iberian and Italian peninsulas. With the 'creation' of America, capitalism gained structural articulation based on the control of labor, resources, and products, serving to shape the new global model of power. Since then, it has inevitably become a colonial/modern and Eurocentric colonial project. Its modernization project is related to a stereotypical vision in capitalism in which 'novelty' or 'innovation' is identified with 'development' or 'progress' (Holliday, 2018).

After the institution of America, Europe became the center of global capitalism by both controlling the world market and imposing colonial rule over all geographic regions and populations, thus incorporating its system and model of world powers (Quijano \& Ennis, 2000). From the $16^{\text {th }}$ century onward, the notion of social, cultural, and racial superiority/inferiority and the idea of dominant/dominated became universal. They served as criteria to classify and subalternize several populations. America (followed by other countries) was colonized under all forms of control and power; labor exploitation and the pacts for distribution to the world market had Eurocentric influences (Gonzalez, 1988).

Eurocentrism also emerged as a new way of systematically producing knowledge. It became globally hegemonic, following the same path as the European bourgeoisie. Western Europe became the center of a modern world system, so intellectuals in the margins started mimicking "ready-made recipes" (Mota-Neto, 2018, p. 8). Thus, ethnocentrism was forged and spread to different regions, based on a categorical, dichotomous, hierarchical logic that is central to modern and capitalist thinking also about race, religion, gender, and sexuality (Ballestrin, 2017; Lugones, 2010).

The Eurocentric knowledge perspective and the coloniality of power have some interdependent dualisms: capital/pre-capital, Europe/non-Europe, primitive/ civilized, traditional/modern. They also contain a linear, one-directional evolutionism and a distorted-temporal relocation based on Eurocentrism, which naturalizes cultural differences by othering, racializing, and gendering (Ballestrin, 2017; Lugones, 2010; Quijano \& Ennis, 2000).

Eurocentric history carries wounds and humiliation from the memories of coloniality. Mignolo (2007a) argued that colonialism is perverse in ensuring that oppressed individuals empty their brains of all forms and content, distorting, disfiguring, and destroying local/ original thinking. Consequently, Eurocentrism involves disseminating the power model of coloniality by an inferior and primitive cognitive aspect (Quijano \& Ennis, 2000).

Decolonial epistemology (DEM) is a proposal to counter colonialism with a vision of human life, by resignifying and rewriting the onto-epistemological reference of knowledge about the "plans of existing, power and thinking” (Mota-Neto, 2018, p. 12). DEM externalizes a colonial history that deals with legal refusals and internal and external power relations, which shaped the global design of a modern/colonial world (Mignolo \& Walsh, 2018). As a component of local (trans)struggle, movements, 
and actions of resistance, DEM is awareness and action that lead to disconnection from the promises of modernity and the inhuman conditions installed by colonialism (Mignolo, 2007a; Walsh, 2007).

Decoloniality subverts the modern/colonial content in the human mind, denaturalizing Eurocentric knowledge (Mota-Neto, 2018). The process involves liberation from the 'rational concept of emancipation,' replacing it with a delinking endeavor to disconnect from the colonial power matrix (Mignolo, 2007a). This disconnection is an initiative of the oppressed/colonized but eventually includes the colonizers since the effects of liberation disconnect both, through the experience of a new pedagogy that brings social change (Freire, 1987; Holliday, 2018).

The delinking project involves recognizing 'coloniality of power' through two simultaneous strands. The first is analytical: opening up the concept of coloniality toward the reconstruction and restitution of silenced stories, repressed subjectivities; knowledge and languages subordinated by the totality portrayed under modernity and rationality. The second strand is programmatic: it refers to 'detachment' actions with individuals and groups in colonial contexts. The intersection of these two strands (analytical and programmatic) moves away from the postcolonial approach, allowing for a decolonial epistemic change (Mignolo, 2007a).

However, Mignolo (2007b) warned that the 'sensible modern or postmodern reader' might think that the decolonial disconnection proposal intends to replace the dominant neoliberal model or its predominant utopian alternative (the socialist-communist system). According to Mignolo, decolonial thought has no such intention as a pluriversal framework, it rejects these two universal summaries.

The decolonial project directs individuals and groups toward a vision of human life that does not depend on a structured and forced imposition of society's ideal (Santos, 2019). Decoloniality is understood as a delinking project that changes the terms of the conversation, not just its content, to denaturalize terminologies and concepts (Mignolo, 2007a).

Abdalla and Faria (2017) proposed the decolonial alternative as a co-construction of the management agenda, fundamental in re-articulating mechanisms and structures that decolonial knowledge and practices have questioned for at least five centuries. Additionally, in the geopolitics of knowledge in emerging semi-peripheries and social struggles (Misoczky \& Camara, 2020), governance is a way of strategically rethinking, for example, family organizations (Faria \& Wanderley, 2013) or cooperatives, agroecological and popular movements (Sauerbronn et al., 2021). Organizations do not follow generic, neutral, and supposedly universal models; they should capture the changing dynamics of co-creating their immediate local reality (Couto, Honorato \& Silva, 2019).

In contrast, Couto, Palhares, and Carrieri (2020) explored the notion of organizational corruption through the lens of Enrique Dussel, who might justify it as the desire to overcome individual injustices by an ethical duty to serve the collective. Silva, André, Wanderley, and Bauer (2020) also appreciated Eurocentric influences in organizational studies, from the perspective of Josué de Castro and the coloniality of power, being, and knowledge. Similarly, Rodrigues and Hemais (2020) historically analyzed the Brazilian System of Advertising Self-Regulation. In the academic field, Bizarria, Tassigny, Barbosa and Freire (2020) considered epistemic decoloniality as a possibility of cultural diversity in university management regarding knowledge plurality.

In accounting education, Mendes, Fonseca, and Sauerbronn (2020) analyzed, through a decolonial lens, aspects of neoliberal ideology in the chapters dealing with accounting principles in the book Contabilidade introdutória (Introductory accounting), written by faculty of the School of Economics and Administration at the University of São Paulo. The book is widely used in several basic training courses in Brazil. Mendes et al. (2020) indicated the need for an educational accounting policy that challenges traditional calculations and techniques, recognizing the role of accounting as a language with its own grammar and structure that ensure the reproduction of neoliberal practices in Brazil.

According to Sauerbronn et al. (2021), accounting studies have shown increasing interest in challenging colonialism. However, several studies still employ postmodern/poststructuralist theoretical frameworks some of them resorting to postcolonial authors in analytical approaches only. None of them develops decolonial programmatic approaches in accounting. Sauerbronn et al. (2021) argue that this would create social and political possibilities, allowing (re)existence as 'other' thoughts and actions to become a strategic tool in the struggle against non-existence, dominated existence, and dehumanization (Walsh, 2007).

Our proposal aligns with Grosfoguel (2012), who shies away from establishing an anti-Western essentialism that produces a binary inversion of Eurocentric logic and ends up reproducing some of the variants of 'thirdworld fundamentalisms' (religious and/or nationalist). In Grosfoguel's perspective, "there are border cosmologies and alternative displacement strategies in the face of Eurocentric fundamentalism (Christian, Zionist, etc.) and third-world fundamentalism (whether Islamists or otherwise)"; those 
are the so-called "border epistemologies, or what Enrique Dussel called transmodernity" (Grosfoguel, 2012, p. 351). Hence, decoloniality in accounting may happen through participatory activities that decolonize knowledge, mind, and bodies (Mignolo, 2007a). The relationship between participants can provide integration and overcome the dichotomy between theory and practice, subject, and object (Fals-Borda, 1979; 2009) from other programmatic approaches (Couto et al., 2019).

\section{COLONIALITY IN RESEARCH AND NON- EXTRACTIVE METHODOLOGIES}

Before addressing non-extractivism, we must revisit colonialism in qualitative studies. To this end, we recognize that the term 'research' is inextricably linked to European imperialism and colonialism (Denzin \& Lincoln, 2005). Modern humanities and social sciences have fostered an imagination about the 'subordinate' social world (the Eastern, the black, the indigenous, the feminine, the peasant), "legitimizing imperial power at the economic and political levels by classifying and ranking epistemologies and identities (personal and collective) of the colonizers and colonized" (Castro-Gómez, 2007, p. 20). Qualitative research has also participated in the excesses of colonialism:

"Knowledge about indigenous peoples was collected, classified, and then represented back to the West ... The research provides the foundation for reports about and representations of 'the Other.' In the colonial context, research becomes an objective way of representing the dark-skinned Other for the white world ... Colonizing nations relied on human disciplines, especially sociology and anthropology, to produce knowledge about strange and foreign worlds ... The agenda was clear-cut: the observer went to a foreign setting to study the culture, customs, and habits of another human group. Often, this was a group that stood in the way of white settlers. Ethnographic reports of these groups were incorporated into colonizing strategies, ways of controlling the foreign, deviant, or troublesome other" (Denzin \& Lincoln, 2005, p. 1).

Based on those methodological excesses, the qualitative research born in the Chicago school of sociology has reinforced Eurocentric coloniality since the 1920s. Reports on observation, participation, interview, and ethnography pertained to a regime of colonial knowledge, power, and truth. These elements originally relate to racism, which was constituted as a "science of EuroChristian superiority" together with the "Aryan model of explanation" (Gonzalez, 1988, p. 71). Such model would become the reference point for positivist evolutionism, which governs the view (and quality evaluation criteria) of Western academic production. According to Lélia Gonzalez (1988), "Europe would transform everything into a task of rational explanation ... then violence will take on new, more sophisticated shapes, not even appearing to be violence, but 'a true superiority"' (Gonzalez, 1988, p. 71).

Qualitative ethnographic research became a powerful tool of othering, also in the accounting field (Kim, 2008). As Jensen (2011) explained, the concept of othering describes identity formation among minorities: the observed/researched are subjected to intersectional othering, with elements of exoticist fascination. According to Santos (2007), traditional qualitative research, based on Eurocentrism, reproduces the existence of a radical dividing line. A single and dominant thought determines that, "on this side of the line," (Santos, 2007, p. 71), there is a relevant reality, including the very historical development of Eurocentric modernity based on triple domination (capitalism, colonialism, and patriarchy).

In accounting, this side of the abyssal line sustains quantitative and qualitative approaches based on neoclassical economics and structural functionalism (Lourenço \& Sauerbronn, 2016). In Brazil, critical studies in accounting are incipient (Azevedo et al., 2020) even if we consider liberal, humanistic, progressive, and Marxist approaches (Sauerbronn et al., 2021). On this side, the qualitative modernizing project comprises an extractive methodology, fostering the appropriation of being, knowledge, culture, and nature without consent (Barbosa, 2018). However, "on the other side of the line," the Eurocentric division dictates that no form of production can be relevant or understandable: "only non-dialectic, invisibility and absence" prevail (Santos, 2007, p. 71).

There is a plurality of knowledge in addition to scientific knowledge and an "infinite epistemological diversity in the world" (Santos, 2007, p. 87). Other methods of inquiry, investigation, and engagement are necessary to overcome the 'knowing-about' a given object of research and develop the 'knowing-with' individuals. Post-abyssal and transmodern thinking ${ }^{2}$ (Mignolo, 2007a) must be built based on non-extractive methods (Santos, 2019) and border thinking ${ }^{3}$ (Mignolo, 2007a).

According to Mota-Neto and Streck (2019), the historical trajectory of popular education from Paulo Freire and Orlando Fals-Borda contributed to the "emergence of a decolonial pedagogy, capable of resisting the subordination of the knowledge and experiences of social subjects marginalized by modernity/coloniality" (Mota-Neto \& Streck, 2019, p. 207). The alignment of Freire and FalsBorda with non-extractive methods emerge as a radical way to change seeing, living, and being in the world (Barbosa, 
2018; Mota-Neto, 2018; Mota-Neto \& Streck, 2019; Pacari, 2008). On the one hand, Paulo Freire is internationally recognized for his developments in popular education and a mode of engagement different from traditional models (Freire, 1987). On the other hand, we have Orlando Fals-Borda, a Colombian critical sociologist, one of the founders of PAR in Latin America since the 1970s (Bringel \& Maldonado, 2016). Both are referred to as thinkers based on a rebellious, subversive, resistant, insurgent, and therefore decolonial pedagogy (Mota-Neto, 2018). The legacies of PAR and Freirean education converge, for a nonextractive method, through "participation, praxis, dialogue, awareness categories" (Mota-Neto, 2018, p. 9), centered on a way of being, feeling, listening, thinking, and looking. These principles face and challenge the dichotomies of "objectivity/subjectivity, reason/emotion, individual/society, culture/economics, psychology/sociology, macropolitics/ micropolitics, faith/science, teaching/learning, researcher/ communities, leadership/people, erudite culture/popular culture, local/global" (Mota-Neto, 2018, p. 10).

Therefore, non-extractivism is an "epistemic disobedience" (Mignolo, 2007a) aiming to exteriorize the hegemony of knowledge hitherto rooted in society, assuming the existence of two elementary principles: (a) exclusion, invisibility, and absence; and (b) identification of knowing 'with' and not 'about' (Fasanello et al., 2018; Santos, 2019). Non-extractivism is about "learning to be" (Mignolo, 2008, p. 323) through "mestizo conscience" - a way of embracing people and certain regions of the world who would have "difficulties in transforming their ideas into competitive ones" (Mignolo, 2008, p. 301). 'To be' and 'being' are also distinguished, which explains the fractures and existential feelings with displacements of different regions of the world, assuming and revealing a pluriversal regionality, as in the case of language translation (Mignolo, 2008).

Adopting non-extractive methodologies implies recognizing that other methods bring exclusion and invisibility to cognitive subjects with specific knowledge (Pacari, 2008; Santos, 2019). That makes them appropriate to decolonial thinking (Ballestrin, 2017). This implies recognizing the urgency of a post-capitalist, post-colonial, post-patriarchal society that would allow the emergence of 'new' knowledge, given that the qualitative individual/ researcher is not neutral to social investigations (Denzin, 2018). Critical researchers must expand non-extractivism into the field of accounting (Lourenço \& Sauerbronn, 2016; Sauerbronn et al., 2021).

Knowledge production with subjects means coproduction, co-creation, cooperation, and co-responsibility regarding the nature of social relations (Mignolo \& Walsh, 2018). Likewise, participatory investigations strengthen the role of knowledge construction from plural voices, which emerge from 'within' the field, 'with' participants (Fasanello et al., 2018; Mota-Neto \& Streck, 2019; Santos, 2019). If the subaltern cannot speak, neither can an intellectual [on their behalf] based on Western epistemes (Ballestrin, 2017).

To this end, the concept of epistemological imagination is an emerging practice based on two ideas. First, 'artisanal knowledge' creates its techniques, validities, and objectivities without rejecting useful methods already recognized by the social sciences (Fasanello et al., 2018; Santos, 2019). Narratives and meanings flourishing from individual and collective experiences in thinking, living, and transforming are central to this new methodology (Barbosa, 2018; Soares \& Machado, 2017). Second, to enable surprising perspectives, researchers accept unexpected knowledge that may emerge. They are open to defamiliarizing meanings and senses and describing them as pieces of embodiment (Barbosa, 2018; Santos, 2007) or collectivized experiences (Soares \& Machado, 2017). A "post-abyssal science" must recognize the "incompleteness of all the knowledge involved in it" and the commitment to promote "the convergence of different interests" (Santos, 2019, p. 214). Such commitment should not be a "variable intellectual interest," but somewhat fixed on "empowering and strengthening the struggles against capitalist, colonialist and patriarchal domination," thus becoming "metacognitive" (Santos, 2019, p. 214).

Pacari (2008, p. 57) proposed that decolonial engagements must occur based on four principles to enact political empowerment. First, proportionality-solidarity must guide policy toward the benefit of the have-nots toward a political economy that manages scarcity instead of celebrating accumulation. Second, complementarity involves the harmonious production and distribution of well-being to the community, instead of exclusive accumulation of wealth for an elite. Third, reciprocity ('Minga') means cooperative work aimed at improving, giving, and receiving: it entails both individual rights and duties. Lastly, correspondence means sharing responsibilities.

The "epistemic Minga" drives researchers' curiosity and humility, stressing the rights and obligations of all to "give and receive" (Pacari, 2008, p. 57).

"Ancestral-community cultures, local realities, present diversities, interculturality have to do with democracy, citizenship, governance, and the State. And, of course, they are also a response to totalitarian globalization and a predatory economic model. Modifying this scenario and upsetting the prevailing asymmetries is the great challenge that indigenous peoples have set out to meet since colonial times. All of you are summoned to this historic Minga, to continue an irreversible path" (Pacari, 2008, p. 59). 
We must resituate and resignify what social science has produced so far, allowing new knowledge to be introduced. This recognizes the researcher in a given social context (such as accounting) as a 'collective intellectual' or an 'activist researcher' (Cooper \& Coulson, 2014). Such engagement seeks to expand researchers' bodily senses of their life experiences, moving away from the false principle of 'objectivity and neutrality' (Barbosa, 2018; Santos, 2019).

\section{Decoloniality of mind and body}

The malaise of contemporary society reifies, fragments, and commercializes human beings through banking education, with dehumanizing consequences in the constitution of subjectivities (Freire, 1987). Cognitive knowledge is materialized, embodied in concrete, collective, or individual bodies: the "body materializes the individual and the social, subject to normative regimes ... non-verbal and unconscious interiorization of certain dispositions of inequality and power" (Fernandes \& Barbosa, 2016, pp. 7174). According to Santos (2019), epistemologies of the South take interest in three types of bodies: (a) the dying, i.e., the body of the provisional end of the struggle; (b) the suffering, which survives and perseveres in the struggle despite pain; and (c) the jubilant, which rejoices with pleasure, party, laughter, dance, singing, eroticism, in all celebration of the body's joy.

Bodies become the locus of the universalization of knowledge that the abysmal modernity of accounting and management pedagogy produces and reproduces on a large scale (Sinclair, 2005). Understanding embodied knowledge allows us to be aware of accounting and management experiences, rendered accessible only through the senses. Santos (2019) indicated the need for: (a) deep vision; (b) deep listening; (c) unintelligible sound; and d) a deep sense of smell, taste, and touch. Therefore, sentipensar (feelingthinking) is part of a world change interconnected with the human mind.

The contribution from popular education movements (Holliday, 2018) to the decoloniality of mind is related to human ethics. Such contribution recognizes several tensions and contradictions historically experienced and deeply connected to the meaning of life. Education as a political stance (not as instruction) becomes one of the "essential factors for the conquest of a more humane world where everyone can live more humanely (and can contribute to others doing so)" (Holliday, 2018, pp. 230-231).

Another important contribution comes from black feminist decolonial thinking. It is the notion of escrevivência (roughly 'writing-living'), coined by Conceição Evaristo, to investigate and produce positional knowledge (Oliveira, 2009). Among several methodological resources, writing uses the author's experience to enable narratives that relate to collective experience (Soares \& Machado, 2017). Escrevivência is based on three elements: body, condition, and experience. It subverts the production of knowledge, based on positioned experiences, to produce an artistic fissure in scientific writing. Through writing, people subjected to crises can find ways to overcome setbacks and continue to exist. Escrevivência is a less extractive approach than traditional qualitative methods such as interviews and the researcher's external reports to the phenomenon observed. Evaristo's method turns to collective understanding by having only one (subalternized/racialized/gendered) writer highlight the intersectionality of race, gender, and colonialism. This one writer would be reconstructing subjects and expressing these 'collective' feelings, sensations, and belongings from experiences of different bodies and minds (Soares \& Machado, 2017).

However, Escrevivencia produces knowledge that is different from the decolonial programmatic action that interests us here. This paper aims to build knowledge collectively by exchanging 'teachings and learnings' and participating in efforts to change/transform a group. Escrevivência could be put into practice within a social/ organizational context as a preliminary step, a form of liberation of the mind/body that precedes engagement in a collective co-construction of actions and solutions based on 'epistemic Minga.'

Hence, we are interested in co-constructed collective actions and their solutions through engagements (FalsBorda, 1979; 2009; Freire, 1987). Based on these elements, we will discuss PAR as a non-extractive methodology suitable for knowledge production 'with' the accounting participants more consciously and engagingly. This is aligned with sentipensar (Escobar, 2007; Fals-Borda, 2009; Gómez, 2019), Minga (Pacari, 2008), and the bodily delinking from colonial struggles (Gonzalez, 1988). Thus, like Freire (1992), we understand that a pedagogy of hope is needed through a collective action that is aware of a right to freedom.

In Latin America - or in racialized local histories in Améfrica - , accounting could be delinked by fostering awareness of white/patriarchal supremacy. Covered by a colonialist and racialized veil, such supremacy is transformed into a matter of "administrative rationality" (Gonzalez, 1988, p. 71). PAR could challenge imperialist reproductions that are imposed from the universal (world) to the individual (region) - disregarding legacies, histories, and experiences -, allowing liberation and flourishing of the mind to recognize/rescue stories and wounds of the (contemporary) continental crossing. 


\section{Decoloniality and participatory action research}

Aiming at transformation from within, the decolonial agenda may parallel Latin American popular education (FalsBorda \& Rahman, 1991) movements that have emerged since the 60s and 70s, "always linked to the processes and social and political movements of the continent" (Holliday, 2018, p. 223). Popular education traces back to the work of Orlando Fals-Borda, who, from 1970 to the 2000s, founded FUNDARCO, the Polo Democrático Alternativo (PDA), and the Fundación Rosca de Investigación e Acción Social (Bringel \& Maldonado, 2016). According to Holliday, popular education is a "socio-cultural phenomenon linked to Latin American history" that comprises multiple practices (ranging from the "greatest informality, to being part of an official public policy") (Holliday, 2018, p. 224). Such practices have a common goal: to embrace and develop critical pedagogies that confront "the authoritarian, reproductive, predominantly schooled model of education and that dissociates theory from practice" (Holliday, 2018, p. 224). Popular education is a philosophy of educational praxis, inspired by Freire (1987), based on politicalpedagogical process centered on the human being as a creative and transforming historical subject that is socially constructed in relationships with other human beings and with the world. Fals-Borda's popular education gave rise to the method of investigación-acción participativa or participatory action research (PAR) - mediated by praxis, which linked the researcher's engagement with subordinate classes with the advancement of sociological knowledge (Bringel \& Maldonado, 2016).

However, given the normativism and positivism origins of accounting research (Annisette \& Cooper, 2017), we ought to bring decoloniality, popular education, and action research (AR) together. Action research is well known in the accounting field (Fogarty, 2018) and suffers from the same tensions as other qualitative methods. Qualitative methods have a broad interpretive, post-experimental, postmodern, feminist, and critical sensitivity that attracts some researchers, while a more positivist and post-positivist type of research serves researchers' intentions (Denzin \& Lincoln, 2005, p. 7), including researchers from accounting (Lodi, Thiollent, \& Sauerbronn, 2018). Consequently, there are conservative scholars who discuss the methodological rigor and scientific criteria adequate to proper AR. This conservative group also aspires to intervene in organizational processes to achieve efficiency or solve administrative problems, in functionalist terms (Lodi et al., 2018). Finally, with a critical and activist inclination, a third group of researchers points to AR's transformative and participatory nature. According to Reason and Bradbury (2012):

"action research is a participatory process concerned with developing practical knowing to pursue worthwhile human purposes. It seeks to bring together action and reflection, theory, and practice, in participation with others, in the pursuit of practical solutions to issues of pressing concern to people, and more generally the flourishing of individual persons and their communities" (Reason \& Bradbury, 2012, p. 4).

AR has different approaches, so PAR can be recognized and differentiated (see Smith, 2007, and Torre, Stoudt, Manoff, \& Fine, 2017). Figure 1 illustrates these insertions in quadrants formed by the following dimensions: knowledge and power; institutional and peoples' agenda.

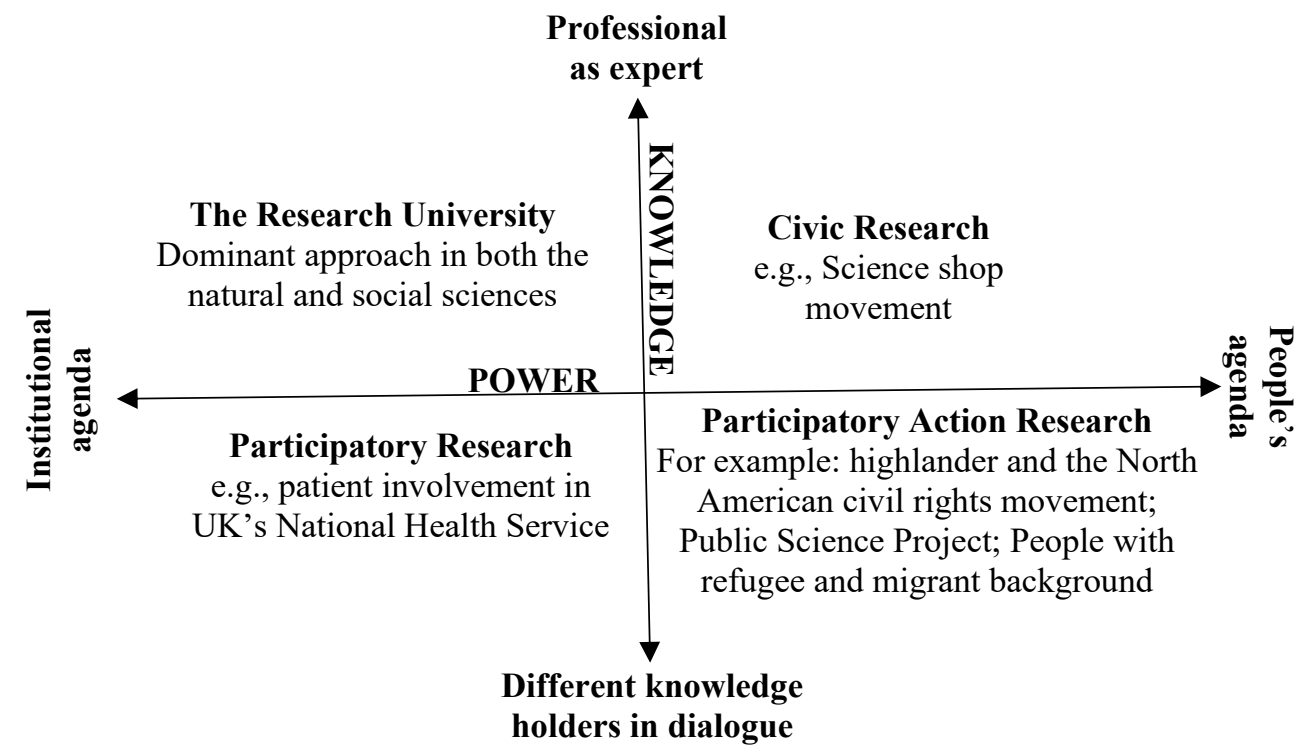

Figure 1. Action research, participation, and research approaches.

Source: Adapted from Wakeford and Rodriguez (2018, p. 24), with reproduction authorization by the authors. 
In Figure 1, researchers in the upper left quadrant identify themselves as 'participatory beings,' holders of knowledge within academia. In the upper right quadrant, researchers maintain a participatory voice but attend to the research agenda of those who have life experience. Researchers move away from the active voice in the lower quadrants, giving space to knowledge holders. In the lower left, they are driven by an institutional agenda, while in the lower right they co-produce based on participants' lived experiences, following a daily and collective research agenda — like a people's agenda.

Hence, from a decolonial epistemology and popular education praxis, the quadrants in Figure 1 must be expanded by rethinking the university's role as the holder of knowledge. Non-extractive decolonial research requires not a university but a multiversity (Mignolo, 2007b) organized according to peoples' cosmology and wisdom. A pluriversity disconnects and moves away from the Eurocentric university and its methods, considering that they contributed to the coloniality of knowledge (Castro-Gómez, 2007). Evidently, we turn to Paulo Freire $(1987 ;$ 1992), Orlando Fals-Borda (1979; 2009) and Fals-Borda and Rahman (1991) to achieve hope, freedom, and emancipation, as they are still recognized today for their contributions to the emergence of a critical PAR proposition, as well as to the development of the decolonial perspective. We appeal to PAR's acclaimed critical and emancipatory dimensions to rethink and reenact it according to the decolonial perspective.

Developing change involves challenging researchers' autonomy due to the logic of power and privilege - arising from universities' ivory tower of knowledge - regarding other participants (Agard et al., 2019; Holliday, 2018). A rupture emerges from establishing trust with participants, based on an ethical epistemology in research, by rescuing each participant's position as an ordinary, social, racialized, beliefholding individual (Mata-Codesal, Kloetzer, \& MaizteguiOñate, 2020). PAR aligns with Fals-Borda's (2009) and Fals-Borda and Rahman (1991) sentipensante neology as an invitation for researchers to tear down university walls and engage with society through PAR. Thus, together with participants, researchers can feel in their own bodies the real experiences of the location in which they live (Santos, 2019). In line with 'epistemic Minga,' it becomes possible for the researcher to break down barriers, deconstruct, rebuild, build urgent thoughts and new knowledge for a change in life and, consequently, in the world (Pacari, 2008; Santos, 2019).

Some features of PAR have been gaining traction in academia as a form of emergent development that acts centrally through the concomitant interaction of four axes: (a) participation and democracy, (b) human flowering, (c) practical issues, and (d) knowledge in action
(Reason \& Bradbury, 2012). Wakeford and Rodriguez (2018) introduced other characteristics, such as improving conditions through repeated cycles of collective action and reflection (Tripp, 2005). According to Wakeford and Rodriguez (2018), if the collective is working on an equal footing, we can raise two related questions: 'who has relevant knowledge?'; 'who should have the power?' These questions may be a starting point for participants to reflect.

Therefore, worldviews can be reconstructed from how people understand the world and how they build and explain it, upon experiences and practices. Both PAR and pluriversality require critical awareness as self-investigation and self-learning processes, describing us as radical humanists (Lykes \& Mallona, 2008). Habermas conceived the universal structure of world identity in the concept of lifeworld. This concept breaks down into (a) culture (the dimension of semantics, tradition, and coherence of knowledge, "valid knowledge"); (b) society (the dimension of social space, group identity, solidarity); and (c) person (the dimension of historical time, history of individual and collective life, personal identities) (Kemmis, 2008, p. 130).

However, an engaged PAR is not free from criticism. On the one hand, positivism and conventional social sciences see PAR as far from the 'scientific' method and unduly classify it as 'activism.' On the other hand, 'hardcore' interpretivism sees PAR as naive because it fails to understand that committing to any course of action is impossible, since all knowledge is contingent and positional. Such argument merely justifies the researcher's own inaction: a "loss of courage in the abyss of endless subjectivity" (Greenwood \& Lewin, 2005, p. 53). Any basic investigation comes from human natural action, including the researcher's action. This is a consequence of human plurality.

\section{Contributions from PAR to Accounting}

To build contextually situated knowledge, a hybrid research objective must embrace some guiding questions: How do participants understand their world? How can we build a different world? What are the practical implications of our work? The researcher may address these issues through methods like discussion groups, PAR, and collaborative history (Wakeford \& Rodriguez, 2018).

PAR allows the researcher to interact with 'blind spots' in traditional research (Wakeford \& Rodriguez, 2018). The interests of PAR originate from co-participants' lives; they do not arise from the investigator's interests or some grand theory. Together, participants and researchers co-create pragmatically useful knowledge based on local experience. In this process, they jointly define research objectives and goals, co-construct research questions, share skills, knowledge, interpretations, texts, and performances, and 
implement specific strategies for social change depending on stakeholders' willingness (Denzin \& Lincoln, 2005).

Therefore, from a decolonial perspective, PAR can serve as a transformational method to deal with multiple voices, disregarded in traditional management and accounting methods and disciplines. Researchers seek to outline the possibility of building a different world that is plural, diverse, and symmetrical, as thought by Freire and Fals-Borda in the early 1970s (Mota-Neto, 2018). From this perspective, Freire (1996) can be thought of for another pedagogy of autonomy in accounting, for other curricula, and other forms of approximation with knowledge of lived reality. In the same way, Fals-Borda and Rahman (1991) contributes to an accounting engagement that may be transformative and political. The breadth of social and revolutionary movements with multiple meanings allows groups and individuals to decide on existence, belonging, and transformation (Dussel \& Ibarra-Colado, 2006).

PAR's emancipatory possibilities align with a critical approach to dominant paradigms in management and accounting. This approach seeks to understand the existing social phenomena that deserve investigation on knowledge and power structures (Lourenço \& Sauerbronn, 2016) and aims to develop militant research (Cooper \& Coulson, 2014). Accounting has been an essential tool for rationalizing capitalist companies (Weber, 1994). In its principles and procedures, accounting is standardized according to legal and fiscal criteria designed to justify and legitimize the capitalist and financialized order, which tames and hides different worldviews from several stakeholders (Capron \& Quairel-Lanoizelée, 2004). While accounting shows the positive results of short-term, maximized profitability, workers' wages and charges appear as simple operating costs to be minimized.

In the last decades, critical accounting approaches have been developed based on several theoretical perspectives, including those derived from Marxism and from the contributions of Habermas, Foucault, Giddens, Bourdieu, and others (Annisette \& Cooper, 2017; Baxter \& Chua, 2003; Gendron \& Baker, 2005; Malsch et al., 2011). Be them small or grand theories, critical approaches to accounting offer informational support for different objectives, such as for unions, NGOs, control entities, and environmental movements. As seen earlier, these approaches still have great emancipatory potential to be developed 'with' different stakeholders by making room for their voices and practices (Cooper \& Coulson, 2014).

In addition to unions and environmental movements, other social actors may be interested in questioning corporations and government accounting, such as in the fight against transfer pricing and tax havens, environmental impact and CSR measures, governance, accountability, and monitoring human rights, gender, and racial violence (Capron \& Quairel-Lanoizelée, 2004).

AR methodology and feasibility have been addressed by previous dissertations and theses on management and accounting in Brazil (Lodi et al., 2018; Soares, Paton, Santos, \& Bezerra, 2009). Faria, Freitas, and Marion (2009) examined the 'management' of losses by applying a target costing system in a company in the plastic industry. Guerreiro, Pereira, Rezende, and Aguiar (2005) looked at the implementation of a budget methodology in a Brazilian organization. In the field of education, Silva, Colle, Cavichioli and Souza (2018) used AR in team-based learning in undergraduate accounting sciences to promote students' commitment to learning, as well as intellectual, functional, and organizational management skills.

Critical accounting also playsa key role in debates about the advantages and disadvantages of privatizations. Critical accounting is also required when bankrupt companies begin a recovery process with workers' participation, negotiating the continuity of activities, including in a cooperative form (Henriques, 2014). Feasibility analysis and accounting expertise are necessary in this context and can incorporate aspects of PAR by involving unions, public authorities, business entities, and other civil society entities.

A research agenda for accounting could focus on organizational dynamics, involving its internal and external users as participants in each location. This would shift the hegemony of knowledge that needs to be communicated, even in different languages, to other necessary and urgent communities. Thus, accounting 'knowledge' can coexist in the duality of theory/practice, without ever connecting to the reality experienced and necessary to daily practices. Some examples include: (a) dialogues on accounting information and knowledge to (re)exist experienced colonial realities; (b) accounting hegemonic technologies (frameworks, managerial controls, governance instruments, etc.) coexisting with local experiences of a given organizational (public, private, community, indigenous) context; and (c) accounting decolonial struggles in teaching and in rethinking professional identities in post-colonial spaces.

In summary, accounting can go well beyond the control of profitability for shareholders, de-centering corporations and focusing on societal demands. Social actors may find and (re) enact several types of accountabilities, governances, and other logics of control and development. Decolonial participatory engagements can (re)contest and (re)inscribe meaning and value to several realities (information and arguments) that accounting sustains in society's contemporary colonial performances. At this point, the possibility of PAR projects associated with accounting is envisaged, defined as internal or external actors' interest in militant research that acts upon and transforms aspects of current socioeconomic practices. 


\section{FINAL CONSIDERATIONS}

This theoretical essay recovers investigaciónacción participativa (Fals-Borda \& Rahman, 1991) and emancipatory pedagogy (Freire, 1987) to present PAR as a non-extractive methodology aligned with the decolonial perspective (Denzin \& Lincoln, 2005; Mignolo, 2007a; Mota-Neto, 2018; Santos, 2019). We extended PAR's potential and scope to accounting and management to challenge its roots in Western modernity, Eurocentrism, and capitalism (Chiapello, 2017; Meneghetti, 2011; Sauerbronn et al., 2021), considering that, based on Eurocentric influences and the imposition of colonial rule, accounting takes over geographies and populations (Alawattage \& Wickramasinghe, 2009; Annisette, 2000; Neu, Everett, \& Rahaman, 2009; Neu \& Heincke, 2004, Oakes \& Oakes, 2016), in sync with a unique and powerful world system (Quijano \& Ennis, 2000).

To face this scenario, non-extractive methodologies have been gaining traction in social research, as a form of emancipatory learning. Emancipation may be possible through the recognition that the individual is a human being with a bodily life, endowed by nature with senses and capable of developing individual and/or collective cognitive knowledge. This asks critical qualitative researchers to rethink, through pedagogy and learning 'with,' about the fact that the world is changing quickly and cyclically, and that fighting oppression and dehumanization is urgent and necessary (Freire, 1987; Mota-Neto, 2018).

'Epistemic emancipation' can (de/re)construct and materialize knowledge in a handcrafted way (Holliday, 2018). The sentipensante proposal creates the possibility of understanding the meaning of engaged and transformative (non-extractive) action, based on the idea that accounting needs to turn itself to society. We hope that the non-extractive methods discussed here can contribute to decolonizing accounting, (re)constructing it as society-centered focused on different groups and needs - instead of being company-centered. This movement can/must recognize the different Latin American identities, positionalities, and groups (black, indigenous, Chicana, quilombola, and queer) related to accounting practice (agroecological, craftsman, social movements/endeavors of the excluded and othered) in different socio-economic, political contexts in the margins of financial capitalism.

This can be a form of transformation and even release from capitalist domination, established by the modern/ Western power system, and imposed by the convergence of accounting standards through national/international organisms. The adequacy of such system to certain spatial and temporal realities can be challenged.

Similarly, the ideas of race and work, which accounting enables and supports, can be problematized because of the dichotomies that entail superiority/inferiority, dominant/ dominated, oppressor/oppressed, objectivity/subjectivity, reason/emotion, local/global, and so on. Co-production, collaboration, and co-creation, which are the basis of PAR, can provide participants with an adequate reality for new knowledge, embodied through mechanisms and instruments co-built from the experiences and voices of the participants themselves. Participants carry distinct worldviews and complexities, which break the subordination of knowledge and marginalized experiences.

\section{NOTES}

1. Escobar (2016) offers a good definition for the term sentipensar: "the terms sentipensar and sentipensamiento are reported by Colombian sociologist Orlando Fals-Borda (1984) as the living principle of the riverine and swamp communities of Colombia's Caribbean coast. [...] They imply the art of living based on thinking with both heart and mind. Sentipensamiento was latter on popularized by the Uruguayan writer Eduardo Galeano as the ability found among popular classes to act without separating mind and body, reason and emotion" (Escobar, 2016, p. 14).

2. As summarized by Sauerbronn et al. (2021), transmodern thinking (and transmodernity) is a non-Eurocentric critical dialogue with alterity that enables recognizing what was denied by coloniality by rescuing non-hegemonic and silenced counter-discourses that constitute modernity itself. It is a project for overcoming modernity, not merely by negating it but by thinking and acting from its underside (the perspective of the excluded Other), seeking liberation by mutual fertilization. See also CastroGómez (2007), Escobar (2007), and Mignolo (2007a).

3. As summarized by Sauerbronn et al. (2021), border thinking moves along the diversity of historical processes, recognizing that there are no original thinking traditions to which one can go back (all have already been 'touched' by modernity and coloniality). Rather than reproducing Western abstract universals, the alternative is to engage the colonialism of Western epistemology (from the left and the right) from the perspective of epistemic subalternized forces (traditional, folkloric, religious, and emotional) (Sauerbronn et al., 2021). 


\section{REFERENCES}

Abdalla, M., \& Faria, A. (2017). Em defesa da opção decolonial em administração/gestão. Cadernos EBAPE.BR, 15(4), 914929. Retrieved from https://bibliotecadigital.fgv.br/ojs/ index.php/cadernosebape/article/view/55249

Agard, C., Ansari, Z., Conner, J., Ferman, B., Pappas, L., \& Shiller, J. (2019). Community-engaged research through the lens of school closures: Opportunities, challenges, contributions, and lingering questions. Education Policy Analysis Archives, 27, 55. Retrieved from https://epaa.asu.edu/ojs/index.php/epaa/article/view/2622

Alawattage, C., \& Wickramasinghe, D. (2009). Weapons of the weak: Subalterns' emancipatory accounting in Ceylon Tea. Accounting, Auditing \& Accountability Journal, 22(3), 379404. https://doi.org/10.1108/09513570910945660

Annisette, M. (2000). Imperialism and the professions: The education and certification of accountants in Trinidad and Tobago. Accounting, Organizations, and Society, 25(7), 631-659. https://doi.org/10.1016/S0361-3682(99)00061-6

Annisette, M., \& Cooper, C. (2017). Critical studies in accounting: Researching the exercise of power. In Z. Hoque, L. D. Parker, M. A. Covaleski, \& K. Haynes (Eds.), The Routledge companion to qualitative accounting research methods (pp. 55-70). Oxfordshire, England: Routledge.

Araujo, W., Rodrigues, L., \& Craig, R. (2017). Empire as an imagination of the center: The Rio de Janeiro school of commerce and the development of accounting education in Brazil. Critical Perspectives on Accounting, 46, 38-53. https://doi.org/10.1016/j.cpa.2016.10.002

Azevedo, S., Barbosa, J., Consoni, S., \& Espejo, M. (2020). Postura ontológica da pesquisa em contabilidade gerencial. Brazilian Journal of Business, 2(3), 2927-2947. Retrieved from https://www.brazilianjournals.com/index.php/BJB/ article/viewFile/16490/13483

Bakre, O. (2014). Imperialism and the integration of accountancy in the commonwealth Caribbean. Critical Perspectives on Accounting, 25(7), 558-575. https://doi.org/10.1016/j.cpa.2013.08.008

Ballestrin, L. (2017). Feminismos subalternos. Revista Estudos Feministas, 25(3), 1035-1054. https://doi.org/10.1590/1806-9584.2017v25n3p1035

Ballestrin, L. (2013). América Latina e o giro decolonial. Revista Brasileira de Ciência Politica, (11), 89-117. https://doi.org/10.1590/S0103-33522013000200004

Barbosa, V. (2018). "Não extrativismo" epistêmico: Desafios à investigação científica crítica. Antropolitica - Revista Contemporânea de Antropologia, (44), 229-255. https://doi.org/10.22409/antropolitica2018.0i44.a41818

Baxter, J., \& Chua, W. (2003). Alternative management accounting research whence and whither. Accounting, Organizations and Society, 28(2/3), 97-126. https://doi.org/10.1016/S0361-3682(02)00022-3
Bizarria, F., Tassigny, M., Barbosa, F., \& Freire, J. (2020). Inovação e gestáo universitária no campo decolonial: Estudo do suporte normativo de uma universidade de integraçáo internacional. Revista Organizaçóes \& Sociedade, 27(95), 855-879. https://doi.org/10.1590/1984-9270959

Bringel, B., \& Maldonado, E. (2016). Pensamento crítico LatinoAmericano e pesquisa militante em Orlando Fals Borda: Práxis, subversão e libertação. Revista Direito \& Praxis, 7(1), 389-413. https://doi.org/10.12957/dep.2016.21832

Capron, M., \& Quairel-Lanoizelée, F. (2004). Mythes et réalités de l'entreprise responsable. Paris: La Découverte.

Castro-Gómez, S. (2007). Decolonizar la universidad: La hybris del punto cero y el diálogo de saberes. In S. Castro-Gómez \& R. Grosfoguel (Eds.), El giro decolonial: Reflexiones para una diversidad epistémica más allá del capitalismo global (pp. 79-91). Bogotá: Siglo del Hombre Editores.

Célérier,L., \&Botey,L.(2015).Participatorybudgetingatacommunity level in Porto Alegre: A Bourdieusian interpretation. Accounting, Auditing \& Accountability Journal, 28(5), 739772. https://doi.org/10.1108/AAAJ-03-2013-1245

Chiapello, E. (2017). Critical accounting research and neoliberalism. Critical Perspectives on Accounting, 43, 4764. https://doi.org/10.1016/j.cpa.2016.09.002

Cooper, C. (2015). Accounting for the fictitious: A Marxist contribution to understanding accounting's roles in the financial crisis. Critical Perspectives on Accounting, 30, 6382. https://doi.org/10.1016/j.cpa.2014.08.002

Cooper, C., \& Coulson, A. B. (2014). Accounting activism and Bourdieu's 'collective intellectual' - Reflections on the ICL case. Critical Perspectives on Accounting, 25(3), 237-254. https://doi.org/10.1016/j.cpa.2013.01.002

Couto, F., Honorato, B., \& Silva, E. (2019). Organizaçóes outras: Diálogos entre a teoria da prática e a abordagem decolonial de Dussel. RAC. Revista de Administração Contemporânea, 23(2), 249-267. https://doi.org/10.1590/1982-7849rac2019180057

Couto, F., Palhares, J., \& Carrieri, A. (2020). Corrupção organizacional e uma justificação decolonial para as práticas de whistleblowing. Revista Eletrônica de Ciência Administrativa, 19(3), 337-358. https://doi.org/10.21529/RECADM.2020014

Davie, S. (2000). Accounting for imperialism: A case of Britishimposed indigenous collaboration. Accounting, Auditing \& Accountability Journal, 13(3), 330-359. https://doi.org/10.1108/09513570010334900

Denzin, N. (2018). Investigação qualitativa crítica. Sociedade, Contabilidade e Gestão, 13(1), 105-119. https://doi.org/10.21446/scg ufri.v13i1.14178

Denzin, N., \& Lincoln, Y. (2005). Introduction: The discipline and practice of qualitative research. In The SAGE Handbook of qualitative research (Chap. 1, pp. 1-32). Thousand Oaks, CA: Sage Publications. 
Dussel, E., \& Ibarra-Colado, E. (2006). Globalization, organization and the ethics of liberation. Organization, 13(4), 489-508. https://doi.org/10.1177/1350508406065852

Escobar, A. (2007). Worlds and knowledges otherwise: The Latin American modernity/coloniality research program. Cultural Studies, 21(2-3), 179-210. https://doi.org/10.1080/09502380601162506

Escobar. A. (2016). Thinking-feeling with the Earth: Territorial strugglesand theontologicaldimensionoftheepistemologies of the South. Revista de Antropologia Iberoamericana, 11(1), 11-32. https://doi.org/10.11156/aibr.110102e

Fals-Borda, O., \& Rahman, M. A. (1991). Action and knowledge: Breaking the monopoly with participatory action-research. Washington, DC: Rowman \& Littlefield Publishers.

Fals-Borda, O. (1979). El problema de cómo investigar la realidad para transformarla por la praxis. Bogotá: Ediciones Tercer Mundo.

Fals-Borda, O (1984). Resistencia en el San Jorge. Bogota: Carlos Valencia Editores.

Fals-Borda, O. (2009). Cómo investigar la realidad para transformarla. In Una sociología sentipensante para América Latina (pp. 253-301). Bogotá: Siglo del Hombre Editores.

Faria, A., Freitas, L., \& Marion, J. (2009). O empreendedor e a aplicação do sistema de custeio-alvo em pequena empresa do segmento de plástico: Uma pesquisa-ação. Revista de Negócios, 14(1), 63-81. https://doi.org/10.7867/1980-4431.2009v14n1p63-81

Faria, A., \& Wanderley, S. (2013). Fundamentalismo da gestáo encontra a descolonialidade: Repensando estrategicamente organizaçôes familiares. Cadernos EBAPE.BR, 11(4), 569-587. https://doi.org/10.1590/S1679-39512013000400007

Fasanello, M., Nunes, J., \& Porto, M. (2018). Metodologias colaborativas não extrativistas e comunicação: Articulando criativamente saberes e sentidos para a emancipaçáo social. Revista Eletrônica de Comunicação, Informação e Inovação em Saúde, 12(4), 396-414. https://doi.org/10.29397/reciis.v12i4.1527

Fernandes, L., \& Barbosa, R. (2016). A construção social dos corpos periféricos. Saúde e Sociedade, 25(1), 70-82. https://doi.org/10.1590/S0104-12902016146173

Fogarty, T. (2018). Action research in accounting. In Z. Hoque, L. D. Parker, M. A. Covaleski, \& K. Haynes (Eds.), The Routledge companion to qualitative accounting research methods (Chap. 14, pp. 231-249). Oxfordshire, England: Routledge.

Freire, P. (1987). Pedagogy of the oppressed (17 ed.). Rio de Janeiro: Paz \& Terra.

Freire, P. (1992). Pedagogia da esperança: Um reencontro com a pedagogia do oprimido. Rio de Janeiro: Paz \& Terra.

Freire, P. (1996). Pedagogia da autonomia: Saberes necessários à prática educativa. São Paulo: Paz e Terra.
Gallhofer, S., \& Haslam, J. (2019). Some reflections on the construct of emancipatory accounting: Shifting meaning and the possibilities of a new pragmatism. Critical Perspectives on Accounting, 63, 101975. https://doi.org/10.1016/j.cpa.2017.01.004

Gendron, Y., \& Baker, C. (2005). On interdisciplinary movements: The development of a network of support around Foucaultian perspectives in accounting research. European Accounting Review, 14(3), 525-569. https://doi.org/10.1080/09638180500041364

Glassman, M., \& Erdem, G. (2014). Participatory action research and its meanings: Vivencia, praxis, conscientization. Adult Education Quarterly, 64(3), 206-221. https://doi.org/10.1177/0741713614523667

Godowski, C., Nègre, E., \& Verdier, M.-A. (2020). Toward dialogic accounting? Public accountants' assistance to works councils - A tool between hope and illusion. Critical Perspectives on Accounting, 69, 102095. https://doi.org/10.1016/j.cpa.2019.102095

Gómez, P. (2019) Sentipensar. In A. Kothari, A. Salleh, A. Escobar, F. Demaria, \& A. Acosta (Eds.), Pluriverse: A postdevelopment dictionary (pp. 302-304). New Delhi: Tulika Books.

Gonzalez, L. (1988). A categoria político-cultural de amefricanidade. Tempo Brasileiro, (92-93), 69-82.

Greenwood, D., \& Lewin, M. (2005). Revitalizing universities by reinventing the social sciences: Bildung and action research. In N. K. Denzin \& Y. S. Lincoln (Eds.), The SAGE Handbook of qualitative research (Chap. 2). Thousand Oaks, CA: Sage Publications.

Grosfoguel, R. (2012). Descolonizar as esquerdas ocidentalizadas: Para além das esquerdas eurocêntricas rumo a uma esquerda transmoderna descolonial. Contemporânea, 2(2), 337-362. Retrieved from https://www.contemporanea. ufscar.br/index.php/contemporanea/article/view/86

Guerreiro, R., Pereira, C. A., Rezende, A. J., \& Aguiar, A. B. (2005). Fatores determinantes do processo de institucionalizaçáo de uma mudança na programação orçamentária: uma pesquisa-ação em uma organização brasileira. Revista de Contabilidade do Mestrado em Ciênncias Contábeis da UERJ, 10(1), 59-76. Retrieved from http://www.atena.org.br/ revista/ojs-2.2.3-08/index.php/UERJ/article/view/679

Henriques, F. (2014). Autogestão em empresas recuperadas por trabalhadores - Brasil e Argentina. Florianópolis: Editora Insular.

Holliday, O. J. (2018). Aportes de los procesos de educación popular a los procesos de cambio social. In A. Guelman, F. Cabaluz, M. Salazar (Coord.), Educación popular y pedagogias críticas en América Latina y el Caribe: Corrientes emancipatorias para la educación pública del siglo XXI (pp. 221-255). Buenos Aires: CLACSO.

Hussain, S., Liu, L., \& Miller, A. (2020). Accounting as a dichotomised discipline: An analysis of the source materials used in the construction of accounting articles. Critical Perspectives on Accounting, 66, 102086. 
Jensen,S.(2011).Othering,identityformationandagency.Qualitative Studies, 2(2), 63-78. https://doi.org/10.7146/qs.v2i2.5510

Kemmis, S. (2008). Critical theory and participatory action research. In P. Reason, \& H. Bradbury (Eds.), The SAGE Handbook of Action Research (pp. 121-138). London: SAGE Publications.

Kim, S. (2004). Imperialism without empire: Silence in contemporary accounting research on race/ethnicity. Critical Perspectives on Accounting, 15(1), 95-133. https://doi.org/10.1016/S1045-2354(03)00004-2

Kim, S. (2008). Whose voice is it anyway? Rethinking the oral history method in accounting research on race, ethnicity and gender. Critical Perspectives on Accounting, 19(8), 1346-1369. https://doi.org/10.1016/j.cpa.2007.03.009

Lassou, P., Hopper, T., Tsamenyi, M., \& Murinde, V. (2019). Varieties of neo-colonialism: Government accounting reforms in anglophone and francophone Africa - Benin and Ghana compared. Critical Perspectives on Accounting, 65, 102071. https://doi.org/10.1016/j.cpa.2019.01.003

Lodi, M., Thiollent, M., \& Sauerbronn, J. (2018). Uma discussáo acerca do uso da pesquisa-ação em administração e ciências contábeis. Sociedade, Contabilidade e Gestão, 13(1), 57-68. https://doi.org/10.21446/scg ufrj.v13i1.14175

Lourenço, R., \& Sauerbronn, F. (2016). Revistando possibilidades epistemológicas em contabilidade gerencial: Em busca de contribuições de abordagens interpretativas e críticas no Brasil. Revista Contemporânea de Contabilidade, 13(28), 99-122. https://doi.org/10.5007/2175-8069.2016v13n28p99 $\begin{array}{ccrr}\text { Lugones, } & \text { M. } & \text { (2010). Toward a } & \text { decolonial } \\ \text { feminism. } & \text { Hypatia, } & 25(4), & 742-759 .\end{array}$ https://doi.org/10.1111/j.1527-2001.2010.01137.x

Lykes, M., \& Mallona, A. (2008). Towards transformational liberation: Participatory and action research and praxis. In P. Reason, \& H. Bradbury (Eds.), The SAGE Handbook of Action Research (pp. 106-120). London:SAGEPublications. https://doi.org/10.4135/9781848607934.n13

Malsch, B., Gendron, Y., \& Grazzini, F. (2011). Investigating interdisciplinary translations. Accounting, Auditing o Accountability Journal, 24(2), 194-228. https://doi.org/10.1108/09513571111100681

Mata-Codesal, D., Kloetzer, L., \& Maiztegui-Ońate, C. (2020). Editorial: Strengths, risks and limits of doing participatory research in migration studies. Migration Letters, 17(2), 201-210. https://doi.org/10.33182/ml.v17i2.934

Mendes, D., Fonseca, A., \& Sauerbronn, F. (2020). Modos de ideologia e de colonialidade em materiais didáticos de Contabilidade. Education Policy Analysis Archives, 28, 99. https://doi.org/10.14507/epaa.28.5061

Meneghetti, F. (2011). O que é um ensaio-teórico? RAC. Revista de Administração Contemporânea, 15(2), 320-332. https://doi.org/10.1590/S1415-65552011000200010

Mignolo, W. (2007a). Delinking: The rhetoric of modernity, the logic of coloniality and the grammar of decoloniality. Cultural Studies, 21(2-3), 449-514. https://doi.org/10.1080/09502380601162647
Mignolo, W. (2007b). Epistemic disobedience: The decolonial option and the meaning of identity in politics. Gragoatá, 12(22), 11-41. Retrieved from https://periodicos.uff.br/ gragoata/article/view/33191

Mignolo, W. (2008). Desobediência epistêmica: A opção descolonial e o significado de identidade em política. Cadernos de Letras da UFF, (34), 287-324.

Mignolo, W., \& Walsh, C. (2018). On decoloniality: Concepts, analytics, praxis. London: Duke University Press.

Misoczky, M., \& Camara, G. (2020). Pensar desde a América Latina em diálogo com a organizaçáo das lutas sociais descoloniais: Explorando possibilidades. RAE Revista de Administração de Empresas, 60(2), 93-103. https://doi.org/10.1590/S0034-759020200203

Mota-Neto, J. (2018). Paulo Freire e Orlando Fals Borda na genealogia da pedagogia decolonial latino-americana. Folios, (48), 3-13. Retrieved from http://www.scielo. org.co/scielo.php?script=sci $\operatorname{arttext\& pid=S0123-}$ $48702018000200003 \& \operatorname{lng}=\mathrm{pt} \& \mathrm{nrm}=\mathrm{iso} \& \mathrm{t} \operatorname{lng}=\mathrm{pt}$

Mota-Neto, J., \& Streck, D. (2019). Fontes da educação popular na América Latina: Contribuiçóes para uma genealogia de um pensar pedagógico decolonial. Educar em Revista, 35(78), 207-223. https://doi.org/10.1590/0104-4060.65353

Neu, D., \& Heincke (2004). The subaltern speaks: Financial relations and the limits of governmentality. Critical Perspectives on Accounting, 15(1), 179-206. https://doi.org/10.1016/S1045-2354(03)00009-1

Neu, D., Everett, J., \& Rahaman, A. (2009). Accounting assemblages, desire, and the body without organs: A case study of international development lending in Latin America. Accounting, Auditing \& Accountability Journal, 22(3), 319350. https://doi.org/10.1108/09513570910945642

Oakes, H., \& Oakes, S. (2016). Accounting colonisation and austerity in arts organisations. Critical Perspectives on Accounting, 38, 34-53. https://doi.org/10.1016/j.cpa.2015.10.005

Oliveira,L.(2009). “Escrevivência” embecosdamemória, deConceição Evaristo. Revista Estudos Feministas, 17(2), 621-623. https://doi.org/10.1590/S0104-026X2009000200019

Pacari, N. (2008). La incidencia de la participación política de los pueblos indígenas: un camino irreversible. In H. C. Carou, \& W. D. Mignolog (Eds.), Las vertientes americanas del pensamiento y el proyecto des-colonial. Madrid: Trama Editorial.

Pereira, R., Constantino, F., Sauerbronn, F., \& Macedo, M. (2019). Pesquisa qualitativa em contabilidade: Um panorama de sua evolução no congresso ANPCONT à luz da literatura internacional. Revista Contemporânea de Contabilidade, 16(41), 204-224. https://doi.org/10.5007/2175-8069.2019v16n41p204

Quijano, A., \& Ennis, M. (2000). Coloniality of power, eurocentrism, and Latin America. Nepantla: Views from South, 1(3), 533-580. Retrieved from https://www.muse.jhu.edu/article/23906

Reason, P., \& Bradbury, H. (2012). The SAGE handbook of action research: Participative inquiry and practice. London: SAGE. 
Rodrigues, L., Craig, R., Schmidt, P., \& Santos, J. (2015). Documenting, monetising and taxing Brazilian slaves in the eighteenth and nineteenth centuries. Accounting History Review, 25(1), 43-67. https://doi.org/10.1080/21552851.2014.946935

Rodrigues, L., Schmidt, P., Santos, J., \& Fonseca, P. (2011). A research note on accounting in Brazil in the context of political, economic and social transformations, 1860-1964. Accounting History, 16(1), 111-123. https://doi.org/10.1177/1032373210373799

Rodrigues, L., \& Hemais, M. (2020). Influências eurocêntricas no Sistema Brasileiro de Autorregulamentação Publicitária: Pesquisa histórica sob uma perspectiva decolonial. Cadernos EBAPE.BR, 18(spe), 794-806. https://doi.org/10.1590/1679-395120200024

Santos, B. (2007). Para além do pensamento abissal: Das linhas globais a uma ecologia de saberes. Novos Estudos CEBRAP, (79), 7194. https://doi.org/10.1590/S0101-33002007000300004

Santos, B. (2019). O fim do império cognitivo: A afirmação das epistemologias do Sul. Belo Horizonte: Autêntica.

Sauerbronn, F., Ayres, R., \& Lourenço R. (2017). Perspectivas pós-coloniais e decoloniais: Uma proposta de agenda de pesquisa em contabilidade no Brasil. Custos e @gronegócio on line, 13(3), 120-148. Retrieved from http://www. custoseagronegocioonline.com.br/numero3v13/OK\%20 7\%20colonialismo.pdf

Sauerbronn, F., Ayres, R., da Silva, C., \& Lourenço, R. (2021). Decolonial studies in accounting? Emerging contributions from Latin America. Critical Perspectives on Accounting, 102281. https://doi.org/10.1016/j.cpa.2020.102281

Shenkin, M., \& Coulson, A. (2007). Accountability through activism: Learning from Bourdieu. Accounting, Auditing \& Accountability Journal, 20(2), 297-317. https://doi.org/10.1108/09513570710741037

Sikka, P. (2008). The internet and potentialities of emancipatory change: Thecaseof theinstitutionsand politicsofaccounting. Critical Perspectives on International Business, 4(1), 75-83. https://doi.org/10.1108/17422040810849776

Silva, A., Vasconcelos, A., \& Lira, T. (2021). Inscriçóes contábeis para o exercício do poder organizacional: $\mathrm{O}$ caso do fundo de emancipação de escravos no Brasil. Revista de Administração de Empresas, 61(1), ee2019-0448. https://doi.org/10.1590/S0034-759020210106

Silva, R., André, R., Wanderley, S., \& Bauer, A. (2020). Josué de Castro e a colonialidade do poder, do ser e do saber: Uma contribuição para a opção decolonial em estudos organizacionais. Sociedade, Contabilidade e Gestão, 15(1), 41-60. https://doi.org/10.21446/scg ufrj.v0i0.21599
Silva, S., Colle, F., Cavichioli, D., \& Souza, R. (2018). Aprendizado e desenvolvimento de habilidades no curso de contabilidade: Uma pesquisa-açấo com o método TeamBased Learning (TBL). Enfoque: Reflexão Contábil, 37(3), 1-19. https://doi.org/10.4025/enfoque.v37i3.39579

Sinclair, A. (2005). Body and management pedagogy. Gender, Work and Organization, 12(1), 89-104. https://doi.org/10.1111/j.1468-0432.2005.00264.x

Smith, L. (2007). On tricky ground: Researching the native in the age of uncertainty. In N. K. Denzin \& Y. S. Lincoln (Eds.), The landscape of qualitative research (pp. 113-143). London: SAGE Publications.

Soares, L., \& Machado, P. (2017). "Escrevivências" como ferramenta metodológica na produção de conhecimento em Psicologia Social. Revista Psicologia Politica, 17(39), 203-219. Retrieved from http://pepsic.bvsalud.org/scielo. php?script=sci abstract\&pid=S1519-549X20170002000 $\underline{02 \& \operatorname{lng}=\text { pt\&nrm }=\text { iso }}$

Soares, M., Paton, C., Santos, A., \& Bezerra, F. (2009). Uma discussão sobre a viabilidade da pesquisa-ação na contabilidade, Revista de Contabilidade e Organizaçôes, 3(7), 109-126. https://doi.org/10.11606/rco.v3i7.34753

Thiollent, M. (1986). Metodologia da pesquisa-ação (2 ed.). São Paulo: Cortez.

Torre, M., Stoudt, B., Manoff, E., \& Fine, M. (2017). Critical participatory action research on state violence: Bearing wit(h)ness across fault lines of power, privilege, and dispossession. In N. K. Denzin \& Y. S. Lincoln (Eds.), The SAGE Handbook of qualitative research (pp. 855-896). Thousand Oaks, CA: Sage Publications.

Tripp, D. (2005). Pesquisa-ação: Uma introdução metodológica. Educação e Pesquisa, 31(3), 443-466. https://doi.org/10.1590/S1517-97022005000300009

Wakeford, T., \& Rodriguez, J. (2018). Participatory action research: towards a more fruitful knowledge. Bristol: University of Bristol and the AHRC Connected Communities Programme. Retrieved from https://assess.technology/wpcontent/uploads/2020/11/Action Research SP-1.pdf

Walsh, C. (2007). Shifting the geopolitics of critical knowledge: Decolonial thought and cultural studies 'others' in the Andes. Cultural Studies, 21(2-3), 224-239. https://doi.org/10.1080/09502380601162530

Weber, M. (1994). Economia e sociedade. Brasília: Editora UnB. 


\section{Authorship}

\section{Cleia Maria da Silva*}

Universidade Federal Rural do Rio de Janeiro, Departamento de Ciências Contábeis e Finanças

Km 07, Zona Rural, BR-465, 23890-000, Seropédica, RJ, Brazil.

Universidade Federal do Rio de Janeiro, Programa de PósGraduação em Ciências Contábeis

Av. Pasteur, n. 250, Sala 250, Urca, 21941-901, Rio de Janeiro, RJ, Brazil.

E-mail: cms_cleia@hotmail.com

(1) https://orcid.org/0000-0001-8160-8365

\section{Fernanda Filgueiras Sauerbronn}

Universidade Federal do Rio de Janeiro, Programa de PósGraduação em Ciências Contábeis

Av. Pasteur, n. 250, Sala 250, Urca, 21941-901, Rio de Janeiro, RJ, Brazil.

E-mail: fernanda.sauerbronn@facc.ufrj.br

(1) https://orcid.org/0000-0002-7932-2314

\section{Michel Thiollent}

Universidade Federal do Rio de Janeiro, Núcleo Interdisciplinar para o Desenvolvimento Social

Av. Pedro Calmon, n. 550, Cidade Universitária, 21941-901, Rio

de Janeiro, RJ, Brazil.

E-mail: m.thiollent@gmail.com

(1) https://orcid.org/0000-0002-6641-2767

* Corresponding Author

\section{Funding}

The authors reported that there is no financial support for the research in this article.

\section{Conflict of Interests}

The authors have stated that there is no conflict of interest.

\section{Copyrights}

RAC owns the copyright to this content.

\section{Authors' Contributions}

$1^{\text {st }}$ author: conceptualization (equal); data curation (equal); formal analysis (equal); fundingacquisition (equal); investigation (equal); methodology (equal); project administration (equal); resources (equal); software (equal); supervision (equal); validation (equal); visualization (equal); writing-original draft (equal); writing-review \& editing (equal).

$2^{\text {nd }}$ author: conceptualization (equal); data curation (equal); formal analysis (equal); fundingacquisition (equal); investigation (equal); methodology (equal); project administration (equal); resources (equal); software (equal); supervision (equal); validation (equal); visualization (equal); writing-original draft (equal); writing-review \& editing (equal).

$3^{\text {rd }}$ author: conceptualization (equal); data curation (equal); formal analysis (equal); fundingacquisition (equal); investigation (equal); methodology (equal); project administration (equal); resources (equal); software (equal); supervision (equal); validation (equal); visualization (equal); writing-original draft (equal); writing-review $\&$ editing (equal).

\section{Plagiarism Check}

The RAC maintains the practice of submitting all documents approved for publication to the plagiarism check, using specific tools, e.g.: iThenticate.

\section{Peer Review Method}

This content was evaluated using the double-blind peer review process. The disclosure of the reviewers' information on the first page, as well as the Peer Review Report, is made only after concluding the evaluation process, and with the voluntary consent of the respective reviewers and authors.

\section{Data Availability}

RAC encourages data sharing but, in compliance with ethical principles, it does not demand the disclosure of any means of identifying research subjects, preserving the privacy of research subjects. The practice of open data is to enable the reproducibility of results, and to ensure the unrestricted transparency of the results of the published research, without requiring the identity of research subjects. 